FACTA UNIVERSITATIS

Series: Physical Education and Sport, Vol. 18, No 3, 2020, pp. 525 - 533

https://doi.org/10.22190/FUPES200723050M

Research article

\title{
THE VERTICAL JUMP AND SPRINT PERFORMANCE AS DETERMINANTS OF AGILITY AMONG MALE ADOLESCENTS
}

\author{
UDC 796.422.12.012.23-053.6 \\ 796.422.431-053.6
}

\section{Zoran Momčilović, Darko Stojanović, Vladimir Momčilović}

\author{
Pedagogical Faculty, University of Niš, Vranje, Serbia
}

\begin{abstract}
The aim of this cross-sectional study was to determine the relationship between the vertical jump (VJ) and sprint performance with agility among male adolescents. The study was conducted on 42 male elementary school students, (age, $13 \pm 0.5$ years). Among the predictor variables, the Squat Jump (SJ) and Countermovement Jump (CMJ) VJ height were assessed by the Optojump (Microgate, Italy) optical system, and sprint times at 5, 10 and 30 $m$ were assessed using the photocells timing system Witty (Microgate, Italy). Agility as a criterion was assessed with the agility T-test, timed also with photocells. Obtained results showed a significant negative relationship between SJ, CMJ and agility ( $r=-0.52 ;-0.58$, respectively) and a positive relationship between sprint times at 5,10 and $30 \mathrm{~m}$ and agility $(r=0.43 ; 0.53 ; 0.57$, respectively). A backward stepwise regression analysis showed that the $C M J$ was the best single predictor of agility $\left(R^{2}=0.34\right)$. The results of this study illustrate that enhancing jump and sprint performance will bring better times in agility performance. Finally, the CMJ has best influence on agility among all the predictor variables.
\end{abstract}

Key words: Relationship, Squat Jump, Countermovement Jump, Sprint, Agility, Adolescents

\section{INTRODUCTION}

Success in variety of sports is dependent on numerous motor skills, but in multidirectional sports where players are engaged in rapid changes of direction and short bouts, power, speed and agility are crucial abilities that can affect performance and advantages in game situations (Bompa \& Haff, 2009; Delextrat \& Cohen, 2009; Garcia-Gil et al., 2018). It has been suggested that agility is one of the determinant factors in upcoming success and optimal performance in younger athletes (Mirkov, Kukolj, Ugarković, Koprivica, \& Jarić, 2010; Lloyd et al., 2013). Development spurt in agility performance occurs in adolescence at

Received July 23, 2020 / Accepted December 18, 2020

Corresponding author: Darko Stojanović

Pedagogical Faculty, University of Niš, Partizanska 14, 17500 Vranje, Serbia

Phone: +381 17422962 • E-mail: darko89_nish@hotmail.com

두 2020 by University of Niš, Serbia | Creative Commons License: CC BY-NC-ND 
approximately the age of 13-14 in male adolescents, which is proportional with the occurrence of peak height velocity (PHV) (Vänttinen, Blomqvist, Nyman, \& Häkkinen, 2011; Lloyd et al., 2013). Therefore, assessment of physical fitness and the identification of performance predictors are important for the selection and screening of young athletes (Norkowski, 2002; Gonçalves, Rama, \& Figueiredo, 2012; Ferreira et al., 2019).

Agility is often defined as a complex set of interdependent abilities needed to change whole-body movement direction, velocity or mode as an answer to stimulus (Sheppard \& Young, 2006; Bompa \& Haff, 2009; Nimphius, Callaghan, Bezodis, \& Lockie, 2018). According to some research, underlying factors of this definition appear to be muscle strength and power with the potential of stretch-shortening cycles (SSCs) as a capacity to perform short sprints and fast changes of direction with a great efficacy (Gabbett, Kelly, \& Shepard, 2008; Castillo-Rodríguez, Fernández-García, Chinchilla-Minguet, \& Carnero, 2012; Spasić, Uljević, Coh, Dželalija, \& Sekulić, 2013). One of the effective training method is plyometric training in order to "learn" and "gain" SSC capabilities in younger athletes (Stojanović \& Kostić, 2002; Stojanović, Jovanović, \& Stojanović, 2012).

A number of previous studies that have investigated the relationship between jump performance and agility reported significant negative correlations between the Squat Jump (SJ), Countermovement Jump (CMJ) and agility most commonly assessed with the T-test (Pauole, Madole, Garhammer, Lacourse, \& Rozenek, 2000; Alemdaroğlu, 2012; Castillo-Rodríguez et al., 2012; Asadi, 2016; Negra et al., 2017). Furthermore, studies that have investigated the relationship between sprint performance and agility also reported significant positive correlations between the T-test and 10 and $20 \mathrm{~m}$ sprints (Negra et al., 2017), 30-m sprint (Alemdaroğlu, 2012), also 20 and 40-yard sprints (Peterson, Alvar, \& Rhea, 2006). Chaouachi and associates (2009) revealed no significant correlations between 5,10 , and $30 \mathrm{~m}$ sprint times and the agility T-test.

From the mentioned previous studies it is evident that the most often used test in the agility assessment was the T-test. It is a standard test of agility with good reliability and validity characteristics (Pauole et al., 2000). It is simple to use (minimal equipment and preparation). The T-test includes speed and four changes in direction. The most accepted field tests used in lower limb power and performance evaluation are the vertical jump (VJ), SJ and CMJ (Stojanović, Čoh, \& Bratić, 2016; Petrigna et al., 2019; Aksović, Kocić, Berić, \& Bubanj, 2020). Scientific literature on how to train agility for children and adolescents in the best possible manner is limited (Lloyd et al., 2013). Optimization of the agility training programs, a correlation analysis with other physical fitness parameters (muscle strength and power, speed, etc.) is needed (Negra et al., 2017).

The aim of this study is to determine the relationship between $\mathrm{VJ}$ and speed performance with agility among male adolescents.

\section{METHODS}

\section{The sample of participants}

A total of 42 seventh grade elementary school male students (age: $13 \pm 0.5$ years; body height $165.78 \pm 8.98 \mathrm{~cm}$; body mass: $56.43 \pm 10.63 \mathrm{~kg}$; body mass index: $20.43 \pm 2.72 \mathrm{~kg} \cdot \mathrm{m}^{-}$ $\left.{ }^{2}\right)$ participated in this cross-sectional study. The study sample involved only students who voluntarily agreed to participate in the study followed by the testing program. Prior to the study, parental consent was obtained for every participant. This study was conducted in 
compliance with the recommendations for clinical research of the World Medical Association Declaration of Helsinki (2013) and the children's privacy was protected by allowing for anonymity. This study was also reviewed and approved by the Ethics Committee of the Faculty of Sport and Physical Education, University of Niš. All of the participants were clinically healthy during the testing protocol.

\section{Procedures}

The testing procedures were carried out in two days. On the first day, anthropometric measurements were taken early in the morning and performance measurements (VJs and sprints) were performed in the afternoon. The agility test was performed on the second day in the afternoon.

Anthropometric measurements. Body height was measured using a Martin anthropometer GPM 101 (GPM GmbH Switzerland) to the nearest $0.1 \mathrm{~cm}$. Body mass was measured with an accuracy of $0.1 \mathrm{~kg}$ using the Omron BF511 digital scale (Omron Healthcare Co, Kyoto, Japan).

Vertical jump. VJ performance was assessed based on the SJ and CMJ using the Optojump (Microgate, Italy). The Optojump system is a dual-beam optical device which detects any interruptions in communication between beams and makes it possible to measure flight and contact times during jumps with an accuracy of $0.001 \mathrm{~s}$. VJs were performed following the Bosco protocol (Bosco, Luhtanen, \& Komi, 1983). The participants performed a standardized warm-up before testing procedure. Jump height was recorded to the nearest $0.1 \mathrm{~cm}$.

Sprint. Sprint performance was assessed by a linear 30-m sprint test with split times at 5 and $10 \mathrm{~m}$. The participants performed two all-out effort $30 \mathrm{~m}$ sprints on an indoor wooden (parquet) court. Before the testing procedure, participants performed a standardized warm-up. The recovery period was approximately 2-3 minutes between the sprints. Sprint and split times were measured with four Witty photocell gates (Microgate, Italy), positioned at the starting line, $5 \mathrm{~m}, 10 \mathrm{~m}$, and finish line, with an accuracy of $0.01 \mathrm{~s}$ (Fig. 1).

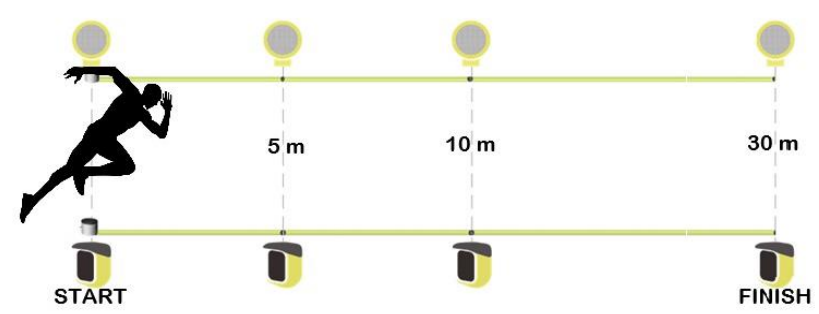

Fig. 1 Graphical layout of linear 30-m sprint test with split times at 5 and $10 \mathrm{~m}$

Agility. Agility was assessed through the T-test following the protocol outlined by Semenick (1990). Time was measured with one Witty photocell gate (Microgate, Italy) mounted on a tripod with a height of $0.75 \mathrm{~m}$ at the starting line, with an accuracy of $0.01 \mathrm{sec}$ (Fig. 2). The reliability and validity of the T-test were confirmed by Pauole et al. (2000). 


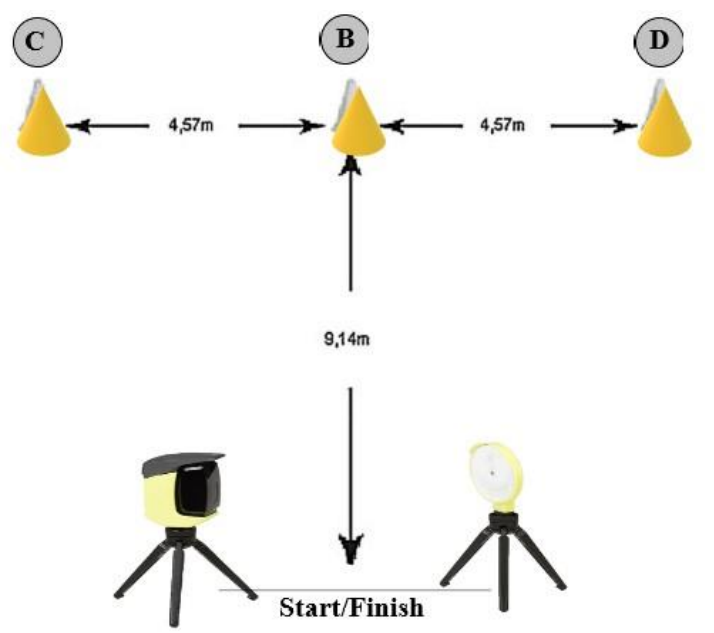

Fig. 2 Graphical layout of the agility T-test

\section{Statistical analyses}

The arithmetic mean (Mean) and standard deviation (SD) values were calculated for each variable. The Kolmogorov-Smirnov test was applied to confirm normality. The relationships between VJ performance, sprint performance and agility were evaluated using Pearson Product Moment Correlation analysis. Cohen (1988) recommended that 0.10 to 0.30 should be interpreted as a weak correlation, 0.30 to 0.50 as a moderate correlation and greater than 0.50 as a strong correlation. A multiple regression analysis with backward stepwise method was used to estimate the best predictor model of agility. Coefficients of determination $\left(\mathrm{R}^{2}\right)$ were used to interpret the proportion of the variance of the T-test that is predictable from the independent variables. Statistical significance was set at level $\mathrm{p}<0.05$.

Statistical procedures and analyses were conducted using the statistical package STATISTICA 10.0 for Windows (StatSoft, Inc., Tulsa).

\section{RESULTS}

The results for the VJ, sprint and agility tests are reported in Table 1 .

Table 1 Descriptive data for all the variables

\begin{tabular}{llrrrr}
\hline$(\mathrm{n}=42)$ & Variable & Mean & \multicolumn{1}{c}{ SD } & \multicolumn{1}{c}{ Min } & \multicolumn{1}{c}{ Max } \\
\hline Vertical & SJ $(\mathrm{cm})$ & 22.77 & 4.73 & 8.90 & 30.50 \\
Jumps & CMJ $(\mathrm{cm})$ & 24.03 & 4.61 & 11.30 & 32.80 \\
\hline \multirow{3}{*}{ Sprint } & 5-m sprint (s) & 1.30 & 0.13 & 1.06 & 1.59 \\
& 10-m sprint (s) & 2.17 & 0.18 & 1.86 & 2.53 \\
& 30-m sprint (s) & 5.53 & 0.43 & 4.69 & 6.51 \\
\hline Agility & T-test (s) & 13.32 & 1.63 & 10.49 & 16.42 \\
\hline
\end{tabular}

Legend: SJ-Squat jump; CMJ-Countermovement jump; SD-Standard deviation. 
The relationship between the performance variables and agility is detailed in a correlation matrix showing the Pearson correlation coefficients $(r)$ in Table 2.

Table 2 Pearson's ( $r$ ) correlation matrix of all variables

\begin{tabular}{lccccc|c}
\hline $\begin{array}{l}\text { Variable } \\
(\mathrm{n}=42)\end{array}$ & SJ $(\mathrm{cm})$ & $\mathrm{CMJ}(\mathrm{cm})$ & $\begin{array}{c}5-\mathrm{m} \text { sprint } \\
(\mathrm{s})\end{array}$ & $\begin{array}{c}10-\mathrm{m} \\
\text { sprint }(\mathrm{s})\end{array}$ & $\begin{array}{c}30-\mathrm{m} \\
\text { sprint }(\mathrm{s})\end{array}$ & T-test (s) \\
\hline $\mathrm{SJ}(\mathrm{cm})$ & 1.00 & $0.87^{*}$ & $-0.36^{*}$ & $-0.51^{*}$ & $-0.70^{*}$ & $-0.52^{*}$ \\
$\mathrm{CMJ}(\mathrm{cm})$ & 1.00 & -0.29 & $-0.44^{*}$ & $-0.67^{*}$ & $-0.58^{*}$ \\
\hline $5-\mathrm{m}$ sprint (s) & & 1.00 & $0.92^{*}$ & $0.65^{*}$ & $0.43^{*}$ \\
$10-\mathrm{m}$ sprint (s) & & & 1.00 & $0.78^{*}$ & $0.53^{*}$ \\
$30-\mathrm{m}$ sprint (s) & & & & 1.00 & $0.57^{*}$ \\
\hdashline T-test (s) & & & & 1.00 \\
\hline
\end{tabular}

Legend: SJ-Squat jump; CMJ-Countermovement jump; *-significant at level $\mathrm{p}<0.05$.

The agility T-test performance was significantly related to all independent variables (Table 2). Negative strong correlations were found in CMJ and SJ ( $\mathrm{r}=-0.58$ and -0.52 , respectively) and a strong positive correlation among sprint times at 30 and $10 \mathrm{~m}(\mathrm{r}=0.57$ and 0.53 , respectively). A moderate correlation was found in 5-m sprint time $(\mathrm{r}=0.43)$.

A multiple regression analysis with a backward stepwise method showed that CMJ was the best single predictor ( $\mathrm{p}=0.000$ ) of agility (Fig. 2).

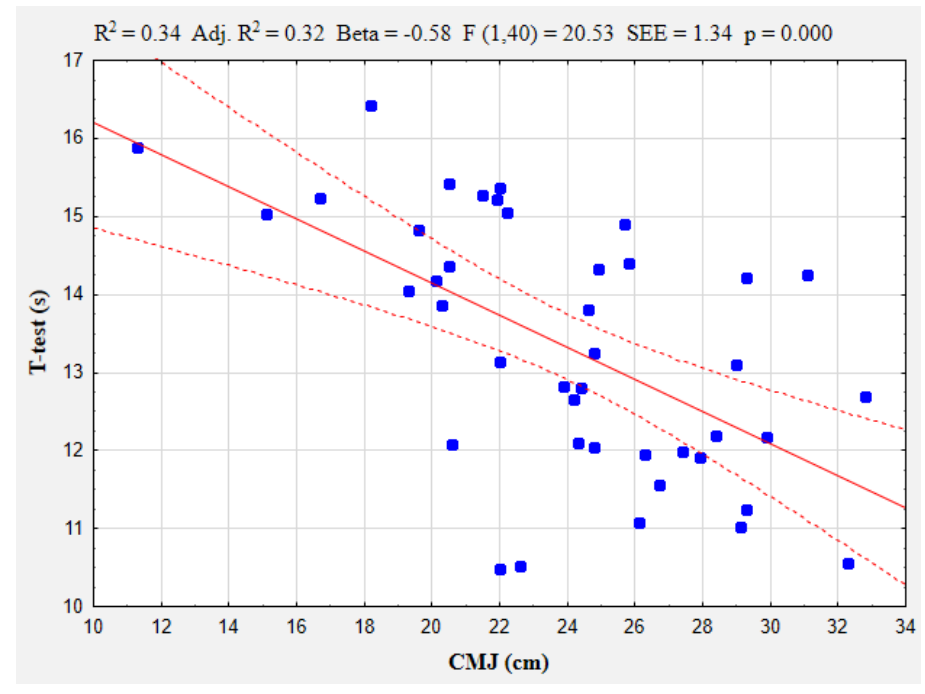

Fig. 3 Linear regression of CMJ as predictor vs. T-test as criteria.

\section{DISCUSSION}

The aim of this study was to determine the relationship between VJ and sprint performance with agility in male adolescents.

The main findings of this study indicate that the agility has a strong correlation with jumping performance and a moderate to strong correlation with straight sprint performance. 
Also, a stepwise regression analysis showed that the CMJ was the single significant predictor of the T-test performance in male adolescents.

Agility is a very complex multifactorial motor ability which is affected by interactions of strength, speed, balance, flexibility, and muscular coordination (Sheppard \& Young, 2006), but it is not yet clear in what proportion they are associated among adolescents. Results from this study clearly demonstrates the presence of a strong negative relationship between jumping performance and agility, indicating that the greater the lower limbs explosive power, the better the time on the agility T-test. In accordance with the obtained results, Negra et al. (2017) reported the same negative relationship between SJ, CMJ and the agility T-test $(\mathrm{r}=-0.53 ;-0.58$, respectively) among adolescent athletes of a similar age to the participants of this study. Alemdaroğlu (2012) also reported a very similar significant negative correlation between the CMJ and T-test $(\mathrm{r}=-0.59)$, but in professional male basketball players. Also, strong correlations were found between jumping performance and the agility test among young basketball players (Asadi, 2016) and students of the Faculty of Physical Education (Castillo-Rodríguez et al., 2012). Pauole et al. (2000) found a moderate significant correlation between the VJ and agility T-test ( $\mathrm{r}=-0.49)$ in college-aged men. However, our results are in contrast with the findings of Peterson, Alvar, \& Rhea (2006) who revealed a trivial to small relationship between the $\mathrm{VJ}$ and the agility T-test in young male athletes, and Chaouachi et al. (2009) found no significant correlation between the SJ, $\mathrm{CMJ}$ and $\mathrm{T}$-test in elite male basketball players.

Furthermore, the results obtained from the correlation matrix showed that sprint performance demonstrates moderate (5-m sprint time) to strong (10 and 30-m sprint times) positive correlations with agility. According to Vescovi and McGuigan (2008), the relationship between speed and agility increases with longer distances and when examining agility with flying sprint times. In accordance with the results of this study, a similar positive relationship was found between the $30-\mathrm{m}$ sprint and $\mathrm{T}$-test $(\mathrm{r}=0.50)$ in elite male basketball players (Alemdaroğlu, 2012), also the 10 and $20 \mathrm{~m}$ sprint and T-test among adolescents (Negra et al., 2017). Peterson and associates (2006) revealed a significant correlation between acceleration (20-yard sprint) and speed (40-yard sprint) with the T-test among young athletes. In contrast, Chaouachi and associates (2009) did not find significant correlations between 5, 10, and $30 \mathrm{~m}$ sprint times and the agility T-test and in elite male basketball players.

The obtained relationship between jumping and sprint performance with agility can be explained by the major role of muscle contraction factors involved during acceleration, deceleration and rapid change of directions. Elastic properties of the muscles and their stored energy utilized from SSC are necessary for maximal jumping, sprint and agility performance (Komi \& Gollhofer, 1997; Young, Miller, \& Talpey, 2015). Also, Hermassi Fadhloun, Chelly, and Bensbaa (2011) outlined that the explosive leg power in the CMJ or $\mathrm{SJ}$ is a significant aspect of total time of the agility T-test.

Finally, with a multiple regression analysis using the backward stepwise method all variables were excluded from the regression model except CMJ as the single best predictor for agility performance. CMJ explains $34 \%$ of agility variance, same as Negra et al. (2017) reported $\left(\mathrm{CMJ}: \mathrm{R}^{2}=0.34\right)$. Other studies showed that jumping performance explains the agility from 25\% (Jones, Bampouras, \& Marrin, 2009; Meylan et al., 2009) up to 46\% (Castillo-Rodríguez et al., 2012) of common variance. Spasić et al. (2013) outlined that agility variance explained by power measures infrequently exceeds $50 \%$. A recent study has also proposed a different approach of agility test measurement by removing the confounding 
factor of large amounts of linear sprinting (Nimphius et al., 2018). For example, the time taken to run a 10-yard $(9.14 \mathrm{~m})$ linear sprint would be subtracted from the time to complete a T-test to calculate the change of direction (COD) deficit which can be a more precise measure of actual agility. The underlying logic behind the COD deficit is that some participants were relying on their better than average acceleration ability (10-m time) to mask their agility performance when assessed using total time (Nimphius et al., 2018). Further studies should investigate the COD deficit in order to gather more precise information about the influence of confounding factors to agility.

\section{CONCLUSION}

From the obtained results from this research, it can be concluded that a significant relationship between jumping and sprint performance with agility exists. Furthermore, lower limb explosive power assessed through the CMJ is best single predictor of agility in male adolescents. The results of this study illustrate the significance of developing lower-body muscular strength and power to enhance jump and sprint performance that will eventually affect overall agility performance in male adolescents.

These findings have practical interest for physical education teachers and coaches which suggests that using a field test such as the T-test for agility and CMJ for jump performance assessment, which is easy to administer, consequently maybe used for physical fitness level assessment, also for training modeling and talent identification among youth non-athletes and athletes. One of the limitations of this study is that the CMJ cannot be used as an accurate predictor of agility because a great portion of variance has been left unexplained.

\section{REFERENCES}

Aksović, N., Kocić, M., Berić, D., \& Bubanj, S. (2020). Explosive power in basketball players. Facta Universitatis Series Physical Education and Sport, 18(1), 119-134.

Alemdaroğlu, U. (2012). The relationship between muscle strength, anaerobic performance, agility, sprint ability and vertical jump performance in professional basketball players. Journal of Human Kinetics, 31(1), $149-158$.

Asadi, A. (2016). Relationship between jumping ability, agility and sprint performance of elite young basketball players: a field-test approach. Revista Brasileira de Cineantropometria et Desempenho Humano, 18(2), 177-186.

Bosco, C., Luhtanen, P., \& Komi, P. V. (1983). A simple method for measurement of mechanical power in jumping. European Journal of Applied Physiology and Occupational Physiology, 50(2), 273-282.

Bompa, T.O., \& Haff, G.G. (2009). Periodization: Theory and methodology of training. Champaign, IL: Human Kinetics.

Castillo-Rodríguez, A., Fernández-García, J.C., Chinchilla-Minguet, J.L., \& Carnero, E.Á. (2012). Relationship between muscular strength and sprints with changes of direction. The Journal of Strength and Conditioning Research, 26(3), 725-732.

Chaouachi, A., Brughelli, M., Chamari, K., Levin, G.T., Ben Abdelkrim, N., Laurencelle, L., et al. (2009). Lower limb maximal dynamic strength and agility determinants in elite basketball players. Journal of Strength and Conditioning Research, 23(5), 1570-1577.

Cohen, J. (1988). Statistical power analysis for the behavioral sciences, $2^{\text {nd }}$ Ed. Hillsdale, NJ: Erlbaum

Delextrat, A., \& Cohen, D. (2009). Strength, power, speed, and agility of women basketball players according to playing position. Journal of Strength and Conditioning Research, 23(7), 1974-1981.

Ferreira, A., Enes, C., Leao, C., Goncalves, L., Clemente, F.M., Lima, R., et al. (2019). Relationship between power condition, agility, and speed performance among young roller hockey elite players. Human Movement, 20(1), 24-30.

Gabbett, T.J., Kelly, J.N., \& Sheppard, J.M. (2008). Speed, change of direction speed, and reactive agility of rugby league players. The Journal of Strength and Conditioning Research, 22(1), 174-181. 
Garcia-Gil, M., Torres-Unda, J., Esain, I., Duñabeitia, I., Gil, S.M., Gil, J., et al. (2018). Anthropometric parameters, age, and agility as performance predictors in elite female basketball players. Journal of Strength and Conditioning Research, 32(6), 1723-1730.

Gonçalves C.E.B., Rama L.M.L., \& Figueiredo, A.B. (2012). Talent identification and specialization in sport: an overview of some unanswered questions. International Journal of Sports Physiology and Performance, 7(4), 390-393.

Hermassi, S., Fadhloun, M., Chelly, M.S., \& Bensbaa, A. (2011). Relationship between agility T-test and physical fitness measures as indicators of performance in elite adolescent handball players. Педагогика, психология и медико-биологические проблемы физического воспитания и спорта, (5), 125-131.

Jones, P., Bampouras, T.M., \& Marrin, K. (2009). An investigation into the physical determinants of change of direction speed. The Journal of Sports Medicine and Physical Fitness, 49(1), 97-104.

Komi, P.V., \& Gollhofer, A. (1997). Stretch reflexes can have an important role in force enhancement during SSC exercise. Journal of Applied Biomechanics, 13(4), 451-460.

Lloyd, R.S., Read, P., Oliver, J.L., Meyers, R.W., Nimphius, S., \& Jeffreys, I. (2013). Considerations for the development of agility during childhood and adolescence. Strength and Conditioning Journal, 35(3), 2-11.

Meylan, C., McMaster, T., Cronin, J., Mohammad, N.I., Rogers, C., \& Deklerk, M. (2009). Single-leg lateral, horizontal, and vertical jump assessment: reliability, interrelationships, and ability to predict sprint and change-of-direction performance. Journal of Strength and Conditioning Research, 23(4), 1140-1147.

Mirkov, D.M., Kukolj, M., Ugarkovic, D., Koprivica, V.J., \& Jarić, S. (2010). Development of anthropometric and physical performance profiles of young elite male soccer players: a longitudinal study. Journal of Strength and Conditioning Research, 24(10), 2677-2682.

Negra, Y., Chaabene, H., Hammami, M., Amara, S., Sammoud, S., Mkaouer, B., et al. (2017). Agility in Young Athletes: Is It a Different Ability From Speed and Power?. Journal of Strength and Conditioning Research, 31(3), 727-735.

Nimphius, S., Callaghan, S. J., Bezodis, N.E., \& Lockie, R.G. (2018). Change of direction and agility tests: Challenging our current measures of performance. Strength and Conditioning Journal, 40(1), 26-38.

Norkowski, H. (2002). Anaerobic power of handball players representing various sport levels. Journal of Human Kinetics, 7, 43-50.

Pauole, K., Madole, K., Garhammer, J., Lacourse, M., \& Rozenek, R. (2000). Reliability and validity of the Ttest as a measure of agility, leg power, and leg speed in college-aged men and women. The Journal of Strength and Conditioning Research, 14(4), 443-450.

Peterson, M.D., Alvar, B.A., \& Rhea, M.R. (2006). The contribution of maximal force production to explosive movement among young collegiate athletes. Journal of Strength and Conditioning Research, 20(4), 867-873.

Petrigna, L., Karsten, B., Marcolin, G., Paoli, A., D'Antona, G., Palma, A., et al. (2019). A review of Countermovement and Squat Jump testing methods in the context of public health examination in adolescence: Reliability and feasibility of current testing procedures. Frontiers in Physiology, $10,1384$. https://doi.org/10.3389/fphys.2019.01384

Semenick, D. (1990). Tests and measurements: The T test. National Strength and Conditioning Association Journal, 12(1), 36-37.

Sheppard, J.M., \& Young, W.B. (2006). Agility literature review: classifications, training and testing. Journal of Sports Sciences, 24(9), 919-932.

Spasić, M., Uljević, O., Čoh, M., Dželalija, M., \& Sekulić, D. (2013). Predictors of agility performance among early pubescent girls. International Journal of Performance Analysis in Sport, 13(2), 480-499.

Stojanović, T., \& Kostić, R.M. (2002). The effects of the plyometric sport training model on the development of the vertical jump of volleyball players. Facta Universitatis Series Physical Education and Sport, 1(9), 11-25.

Stojanović, N., Jovanović, N., \& Stojanović, T. (2012). The effects of plyometric training on the development of the jumping agility in volleyball players. Facta Universitatis Series Physical Education and Sport, 10(1), 59-73.

Stojanović, N., Čoh, M., \& Bratić, M. (2016). The role of countermovement in the manifestation of explosive leg strength in vertical jumps. Facta Universitatis, Series Physical Education and Sport, 14(1), 13-22.

Vänttinen, T., Blomqvist, M., Nyman, K., \& Häkkinen, K. (2011). Changes in body composition, hormonal status, and physical fitness in 11-, 13-, and 15-year-old Finnish regional youth soccer players during a twoyear follow-up. Journal of Strength and Conditioning Research, 25(12), 3342-3351.

Vescovi, J.D., \& McGuigan, M.R. (2008). Relationships between sprinting, agility, and jump ability in female athletes. Journal of Sports Sciences, 26(1), 97-107.

Young, W.B., Miller, I.R., \& Talpey, S.W. (2015). Physical qualities predict change-of-direction speed but not defensive agility in Australian rules football. Journal of Strength and Conditioning Research, 29(1), 206-212. 


\section{VERTIKALNI SKOK I SPRINT KAO DETERMINANTE AGILNOSTI ADOLESCENATA MUŠKOG POLA}

Sa ciljem da se utvrdi povezanost vertikalnih skokova, sprinta i agilnosti dečaka adolescenata, sprovedeno je istraživanje na uzorku od 42 ispitanika muškog pola, učenika sedmog razreda, prosečne starosti $13 \pm 0.5$ godina. Prediktorske varijable su činile visina vertikalnih skokova koja je procenjena pomoću testova skok iz čučnja (SJ) i skok sa počučnjem (CMJ), primenom Optojump sistema, zatim brzina sprinta na $30 \mathrm{~m}$ sa prolaznim vremenom na 5 i $10 \mathrm{~m}$ primenom fotoćelija. Agilnost kao kriterijumska varijabla je procenjena pomoću Agility T-test. Dobijeni rezultati ukazuju da postoje značajne negativne korelacije između vertikalnih skokova SJ, CMJ i agilnosti $(r=-0.52 ; r=-0.58$, tim redosledom), kao i značajne pozitivne korelacije između brzine sprinta na 5 , 10 i 30 m i agilnosti (r=0.43; 0.53; 0.57, tim redosledom). Stepwise regresiona analiza je pokazala da je varijabla $C M J$ jedini značajni prediktor agilnosti $\left(R^{2}=0.34\right)$. Zaključuje se da su vertikalni skokovi i sprint značajno povezani sa agilnošću kao veoma kompleksne motoričke sposobnosti, takođe vertikalni skok CMJ ima najveći uticaj razvoj brzine izvođenja testova agilnosti.

Ključne reči: povezanost, skok iz čučnja, skok sa počučnjem, sprint, agilnost, adolescenti. 